Kinestetik : Jurnal Ilmiah Pendidikan Jasmani 5 (2) (2021)
Kinestetik : Jurnal Ilmiah Pendidikan Jasmani
https://ejournal.unib.ac.id/index.php/kinestetik/index
DOI : 10.33369/jk.v5i2.16781

\title{
EVALUATION STUDY ON TEACHER COMPETENCY PHYSICAL EDUCATION, SPORTS AND HEALTH (PJOK) IN PESAWARAN DISTRICT
}

\author{
Rahmat Hermawan \\ Department of Physical Education, Education Sciences, Universitas Lampung, Bandar \\ Lampung, Indonesia
}

\section{Article Info}

Article History :

Received : June 2021

Revised : June 2021

Accepted : June 2021

Available online : June 2021

\section{Keywords:}

Competence, pedagogic, personality, social, professional

\begin{abstract}
Based on observations so far, physical education and sports teachers in Lampung in the implementation of their learning have not been effective(Hermawan, 2020), is no exception, of course, in Pesawaran Regency. This study aims to obtain a general description of the competence of physical education and sports teachers in Pesawaran Regency, including pedagogic, professional, personality, and social competencies.Method research used is survey method with qualitative descriptive approach. The population of this research isall PJOK teachers (SD, SMP and SMA/SMK) in Pesawaran Regency, as many as 136 people. Data collection techniques using instrumentsobservations, interviews, documentation and questionnaires. Data analysis usingqualitative descriptive analysis approach through triangulation, and the results of the study can be concluded namely (1) The profile of PJOK teachers in Pesawaran is generally still relatively productive, which is in the range of 31-35 years, namely 37 people $(27.21 \%)$ and in the age range $41-45$ years, namely 36 people (26.47\%)especially for elementary school teachers, (2) the pedagogical competence of teachers is in accordance with the provisions of the legislation, namely being able to (a) understand students, (b) make learning designs, (c) carry out conducive learning, and (d) design and carry out evaluations of learning outcomes on an ongoing basis, (3) In terms of personality competencies, teachers have behaviors that can be imitated by students, (4). In terms of social competence, the teachers are able to communicate and interact effectively with various parties, and (5) In terms of professional competition, most of the teachers have obtained certification, namely 94 people $(65.12 \%)$.
\end{abstract}

Corresponding address : Jl. Prof. Dr. Ir. Sumantri Brojonegoro

No.1, Gedong Meneng, Kec. Rajabasa, Kota Bandar Lampung,

ISSN 2685-6514 (Online)

Lampung

ISSN 2477-331X (Print)

*Corresponding email : Nugafik@yahoo.co.id 


\section{INTRODUCTION}

The phenomenon that occurs in several areas in Lampung, especially in Pesawaran Regency is that physical education and health (PJOK) teachers lack the ability to interpret the curriculum so that it affects their performance. Whereas according to Hermawan and Jubaedi (2015: 80) that the success of learning physical education in schools is largely determined by the role and ability of a teacher in implementing various knowledge that has been obtained in college, such as the application of learning models, mastery of learning methods, and evaluation.

Likewise, one of the obstacles to the lack of smooth learning of physical education in schools, especially in elementary schools, is the inadequate facilities and infrastructure owned by the school (Hahagia, Y., 2011). In addition, there is still a strong dependence of PJOK teachers on standard facilities and learning approaches to the presentation of standard basic techniques as well. These two things cause learning patterns that are less varied and tend to be boring for students. In addition, several previous research reports in various regencies/cities in Lampung) show that currently the facilities and infrastructure for physical education learning activities in schools, from elementary to high school (SMA) are still apprehensive (Hermawan, 2020). In addition, the factor that should not be ignored and the most affecting a teacher's work performance is the environment (workplace), as revealed by Eliyanto (2018) from the results of his research, that a comfortable work environment for teachers can improve teacher performance. On the other hand, an uncomfortable work environment will reduce motivation and ultimately reduce teacher performance. This is in line withRahmawanti et al. (2014) that the environmentn pleasant work can make employees feel at home in completing their work and able to achieve an optimal result.

Teachers as professions are demanded with various expectations, as role models, figures who have skills and knowledge that are quite qualified from their students so it is not surprising that teachers in various regions become role models who are always imitated, especially in today's world of complex global changes, so teachers Professionalism is also required (Hermawan, 2008).

\section{METHODS}

Because in accordance with the nature of the problem and the research objectives to be obtained and not testing hypotheses, the authors conducted qualitative research but tried to obtain a real picture of how the competence of PJOK teachers was implemented. Research with a qualitative approach is according to Sugiyono (2009:15) that: "Qualitative research is a research method based on the philosophy of postpositivism, used to examine the condition of natural objects where the researcher is the key instrument, sampling of data sources is carried out manually. purposive and snowball, triangulation collection techniques, inductive data analysis, and qualitative research results emphasize meaning rather than generalization."

\section{Participants}

The respondents of this study were all PJOK teachers starting from elementary school (SD), junior high school (SMP), and high school (SMA) teachers totaling 136 people. 


\section{Sampling Procedure}

The sample is taken as a whole from the existing population, so the sample can be called a porpusive sample or sample as it is.

\section{Materials and Equipment}

The materials and tools used in this research are in the form of a questionnaire (questionnaire), interview guidelines, documentation in the form of profiles and curriculum vitae of teachers in their respective schools, as well as observation guidelines.

\section{Procedure}

Data were collected through observation, interviews, documentation and questionnaires, then analyzed by triangulation in order to obtain a clear picture of the objectives to be achieved from this research, then displayed as research findings and presented in several aspects or competencies, including pedagogic, professional, personality and social

\section{Data analysis}

To process the research data, the researcher took the following steps: (1) Data reduction. This stage was carried out to make abstractions of all data obtained from the field in accordance with the research focus. (2) The organization and processing of data is carried out in accordance with the research objectives. The scattered data is adjusted to make it easier to interpret. (3) The interpretation of the data is in accordance with the research objectives, namely assembling the elements of research data to reach a conclusion in accordance with the overall and continuous research objectives, and (4) Data verification is carried out to test or check the conclusions drawn compared to the theories that relevant whether it is appropriate or not in achieving the research objectives.

\section{RESULT}

PJOK Teacher Profile in Pesawaran

Based on Permendiknas No. 16 of 2007 that teacher competencies consist of: (1) pedagogical competence, professional competence, (3) personality competence, and (4) social competence (in Pujianto and Insanistyo (2014). Before reviewing the competence of physical education and sports teachers in Pesawaran Regency, it is good to see the extent ofthe teacher's profile.

Table 1. Certification of Respondents

\begin{tabular}{ccccc}
\hline \multirow{2}{*}{$\begin{array}{c}\text { Undertaking } \\
\text { Certification }\end{array}$} & \multicolumn{2}{c}{ Already } & \multicolumn{2}{c}{ Not yet } \\
\cline { 2 - 5 } & Men & Woman & Men & Woman \\
\hline SD & 18 & 10 & 12 & 10 \\
\hline middle school & 34 & 6 & 21 & 1 \\
\hline high school & 13 & 3 & 6 & 2 \\
\hline amount & $\mathbf{7 5}$ & $\mathbf{1 9}$ & $\mathbf{3 9}$ & $\mathbf{1 3}$ \\
\hline
\end{tabular}

In general, teachers PJOK in Pesawaran Regency the majority of men as many as 104 people $(74.47 \%)$ and women as many as 32 people $(25.53 \%)$. which are spread at the elementary, junior high, and high school / vocational education levels. And most of them are at the elementary school level. Meanwhile, in terms of age, teachersphysical education and sports in Pesawaran, the majority are in the range of 31-35 years, namely 37 people $(27.21 \%)$ and in the age range of 41-45 years, namely 36 people $(26.47 \%)$. While the rest spread to other age ranges, except for those under 25 years old, none. Likewise for the tenure, ron average the majority are in the 11-15 year old as many as $42(33.82 \%)$, in the $16-20$ year range as many as 26 people (19.12\%), and in the 21-25 year range as many as 17 people $(12.50 \%)$, while the rest are spread over various ranges. 


\section{Pedagogical Competence}

Based on interviews and observations, pedagogical competencies for PJOK teachers in Pesawaran in general have the ability to (1) understand the characteristics of students, (2) make learning designs, (3) carry out conducive learning, and (4) design and carry out continuous evaluation of learning outcomes

\section{Personal Competence}

The results of interviews with ordinary teachers $(\mathrm{M})$, the principal of SMP 17 Pesawaran (S) and the head of the field (Head of) basic education (AH), said that: "In general, sports teachers are easy to get along with and familiar with so they can easily adapt to their environment. So, we don't hesitate to ask for any help, such as ceremonies, scouts, or other out-of-school activities." However, there are also many sports teachers who are not healthy, such as smoking and have a distended stomach" and "there are still some sports teachers who teach undisciplined, namely wearing ordinary clothes when teaching in the field".

\section{Social Competence}

By helping other parties, it can be said that physical education and sports teachers in general already have social competence. Activities in the community such as participating in community service, celebration committees, funeral committees and other voluntary activities.

The number of activities as stated above will of course foster communication with various parties, especially competition or competition activities, a lot of communication occurs, both with students as athletes, with parents of students, with opposing officials, with spectators, with referees, and etc. Communication will grow if it starts from the family, therefore the cultural or ethnic background will affect the ability to communicate.

\section{Professional Competence}

From the results of the interviews obtained some information that the majority of PJOK teachers have obtained educator certificates. This is like the acknowledgment that was conveyed including $\mathrm{R}$ said as follows; "I am happy to be certified so that I can receive allowances, to increase the cost of household expenses or family economics", Likewise the opinion of $\mathrm{BH}$ and $\mathrm{S}$, who happened to be both certified because of the age limit, "Thank God, having certification can help our financial difficulties, especially helping the cost of our children who are studying in college"

From some of the opinions above, it can be concluded that the existence of certification for teachers has increased their income, so that aspects of welfare have also increased. Similarly, their responses about the importance of implementing PPG, all teachers from elementary, middle and high school/vocational schools gave similar comments that the activity was felt to be very helpful in the implementation of learning in their respective schools. While their responses to the PLPG/PPG material which are very relevant to teaching assignments, all teachers agreed that they should make learning programs, physical education learning activities and develop learning tools, especially lesson plans. Likewise, what material is difficult to accept while participating in the PLPG, all of them answered the CAR, this is because the content or material is too difficult to understand, even if they have graduated. It can be concluded that in general, physical education and sports teachers are very low in scientific understanding.

\section{DISCUSSION}

PJOK teachers in Pesawaran Regency are 136 peoplethe majority were men, namely 104 people $(74.47 \%)$ and women, namely 32 people (25.53\%). which are spread at the elementary, junior high, and high school / vocational school levels. Most are at the elementary level). While the average age ranges from 31-35 years (37 people $=27$, $21 \%$ ) and in the age range of $41-45$ years, namely 36 people $(26.47 \%)$, this shows that their age is still relatively productive. This situation is very supportive of their duties to the fullest.Judging from the status, it turns out that some of the civil servants (PNS) 
amounted to 91 people $(66.91 \%)$ the most were elementary school teachers, while honorary staff were 45 people $(33.08 \%)$. This is in line with the view that Suryobroto, Agus S (2005) stated that the task of physical education teachers is not only to convey material that is physical and motoric, but all domains must be conveyed to their students through complete learning and education. So successful learning must go through various kinds of activities, both physical and psychological activities, and this situation can be achieved if they are of a productive age.

In accordance with Law No. 14 of 2005 concerning teachers and lecturers, which is quoted by Ginting in Mulyasa (2008) namely "To be able to carry out his professional duties properly, a teacher must have four core competencies namely pedagogic competence, personality competence, social competence, and professional competence". Based on the law, it is stated that a teacher in carrying out his duties must be guided by four competencies, namely pedagogic, personality, social, and professional. Another part of the law states that teachers are professional educators with the main task of educating, teaching, guiding, directing, training, assessing, and evaluating students (Kemendiknas, 2010). Therefore, it would not be an exaggeration ifPrincess and Priambodo (2015) defines that teacher's job is a professional educator with the main task of educating, teaching, guiding, directing, training, assessing and evaluating students in early childhood education through formal education, basic education, and secondary education.

\section{Pedagogic Competence}

The findings through interviews and observations, that the pedagogical competence of PJOK teachers in Pesawaran Regency is appropriate, namely having the ability to (1) understand the characteristics of students, (2) make learning designs, (3) carry out conducive learning, and (4) design and carry out evaluations of learning outcomes continuously. This corresponds toMulyana (2017:41) explains that out of 10 pedagogical competencies, there are at least five that are appropriate, including (1) mastering the characteristics of students from physical, moral, social, cultural, emotional, and intellectual aspects, (2) mastering theory learning and teaching principles of learning, (3) mastering the curriculum related to the field of development being taught, (4) being skilled at carrying out appropriate development activities

educating, and (5) skilled in assessing and evaluating learning processes and outcomes,

And in line with Draft Teacher Government Regulation No. 19 of 2005 as quoted by Mulyasa (2007) that: "Pedagogic competence is the ability of teachers in managing student learning at least to be able to (a) design learning, (b) implement learning, (c) utilize learning technology, (d) ) Evaluation of Learning Outcomes (EHB), and (e) developing students to actualize their various potentials.

\section{Personal Competence}

Research findings through observations and interviews based on several sources, including ordinary teachers (S), school principals (M) and heads of basic education (AH) fields, said that: "In general, they are easy to get along with and familiar with so they can easily adapt to environment. So, we do not hesitate to ask for any help such as ceremonies, scouts, or other out-of-school activities" However, "there are still sports teachers who are not healthy, such as smoking and have a distended stomach", and "there are some sports teachers who teach not discipline, namely wearing 
ordinary clothes when teaching in the field".

From the opinions of several sources above, it can be concluded that the personality of teachers is generally quite positive, namely easy to get along with and work together. This is in accordance with the description of personality competenceas explained by Mulyana (2017), namely (1) acting in accordance with Indonesian religious, legal, social and national cultural norms, (2) presenting oneself as an honest person, having noble character, and an example for students and the community, (3) present oneself as a person who is steady, stable, mature, wise, and authoritative, (4) demonstrates a work ethic, high responsibility, pride in being a teacher, and self-confidence, and (5) upholds the code of ethics of the teaching profession. This situation is also in line with the Ministry of National Education (2011) is a mature personality, namely independence in acting as an educator and having a work ethic as a teacher. As well as Daharti et al. (2013) adds that personality competence is a personal ability that reflects a personality that is steady, stable, mature, wise and authoritative, being a role model for students, and having noble character. Be a good PJOK teacher personality has a very big influence on the personal growth and development of students.

\section{Social Competition}

Based on the results of interviews and observations, that from the aspect of social competence there are many activities that have been carried out both at school and in the community, this is evidence of the growth of communication with various parties, especially competition activities or competitions, there is a lot of communication caused, both with students as athletes., with parents of students, with opposing officials, with spectators, with referees, and so on. Communication will grow if it starts from the family, because of that cultural or ethnic background will affect the ability to communicate. This is in accordance with the explanation of the Ministry of National Education (2011), namely being able to communicate and interact effectively with students, with fellow educators and education staff. Likewise, according toDaharti et al. (2013) that kSocial competence is the ability of teachers to communicate and interact effectively with students, education staff, parents/guardians of students, and the surrounding community..Even Mulyana (2017) emphasizes that the social competence of teachers is able to communicate effectively, empathetically, and politely with fellow educators, education staff, parents, and the community, as well as being able to communicate with their own professional community and other professions orally and in writing.

\section{Professional Competence .}

The results of the research findings show that the academic qualifications or level of education that have been undertaken by most of the PJOK teachers are in accordance with professional competence, this is in accordance with the Permendiknas no. 16 of 2007 which is the minimum academic qualification that a teacher must have is $\mathrm{S}$ 1/D-IV relevant to the subjects taught by the educator(Kemendiknas, 2011). As well as Daharti et al. (2013) thatprofessional competence is the mastery of learning materials broadly and deeply, which includes mastery of curriculum material in school subjects and the scientific substance that overshadows the material, as well as mastery of the structure and scientific methodology.

The data obtained that Most of the PJOK teachers in Pesawaran have obtained certificates. There for escertification is very important for teachers to fulfill the mandate of the Republic of Indonesia Law Number 20 of 
2003 concerning National Education System Article 61 states that certificates can be in the form of diplomas and certificates of competence.Furthermore, Mulyana (2017) emphasizes that professional competence, in addition to mastering the material, structure, concepts, and scientific mindset that supports the subjects taught, also masters the competency standards and basic competencies of the subjects/fields of development being taught. Therefore, the scope of professional competence that must be mastered by a teacher is at least "Theory and practical application of teaching materials or fields of study that are his responsibility in the task of organizing learning and learning activities in accordance with the demands of actual scientific and technological developments. according to the potential possessed by students" (Kemendiknas, 2009).

\section{CONCLUSION}

The results of the study can be concluded as follows:

1. Most of the physical education and sports teachers on duty in Pesawaran Regency are relatively young, this shows that this age is still relatively productive, especially for elementary school teachers.

2. Kpedagogic competence the teachers are in accordance with the provisions of the legislation, namely (1) able to understand the students, (2) able to make learning designs, (3) able to carry out conducive learning, and (4) able to design and carry out evaluation of learning outcomes on an ongoing basis

3. Professional competition most of the teachers have attained S1 education and have obtained certification.
4. The personality competencies of teachers have behaviors that can be imitated by students.

5. The social competence of the teachers has been able to communicate and get along effectively with various parties.

\section{REFERENCES}

Arikunto and Cepi. (2009). Evaluation of Educational Programs. Jakarta. Earth Literature.

Happy, Y. (2011). Use of Simple Tools To Increase Sprint Running Speed. (Paper). Presented at the Komnas Penjasor Seminar at the Jica Building, UPI Bandung, September 27, 2011.

Daharti1, R., et al. (2013). Teacher Competency Improvement Strategy with the Hierarchy Process Analysis Approach. TRACK Journal of Economics and Policy 6 (1) (2013): 80-92

Eliyanto (2018). The Influence of Work Motivation and Work Environment on the Performance of Muhammadiyah High School Teachers in Kebumen Regency. Journal of Madrasah Education. Volume 3, Number 1 May 2018. p. 169-181

Hamalik, O. (2009). Teacher Education (Based on Competency Approach). Jakarta. Earth Literature.

Husdarta. HJS (2009). Physical Education Management. Bandung. Alphabet.

Hermawan, R. (2008). Certification Is Recognition of the Teacher's Profession. Papers. Presented in a One Day Seminar for Physical Education Teachers throughout 
Pangalengan District, Bandung Regency, March 20, 2008.

Hermawan, R. (2014). Evaluation Study on the Competence of Physical Education Teachers in Pringsewu Regency. (Research Report). LPPM, University of Lampung. Bandar Lampung.

Hermawan, R., et al. (2014). Evaluation

Study on the Competence of Physical Education Teachers in West Tanjungkarang District, Bandar Lampung City. Journal of Progressive Education (JPP) Volume

4, Number 1 FKIP-ISPI, University of Lampung. Bandar Lampung.

Husin and Hermawan (2015). Evaluation Study of Metro City Physical Education Teacher Competencies (Research Report). LPPM, University of Lampung. Bandar Lampung

Hermawan, R. (2020). Study on the Competence of Physical Education Teachers in West Lampung Regency. Kinesthetic; Journal of Physical Education. 4(1), p.90-98

Ministry of National Education, (2009).

Law on Teachers and Lecturers No. 14 yrs. 2005. Jakarta. Graphic Ray. Ministry of National Education. (2010).

Teacher Certification in Position in 2011, Book 1 Guidelines for Participant Determination. PMPTK Director General. Jakarta.

Ministry of National Education (2011)

Subjects Physical Education

Module.A. Teacher Certification PLPG in the position in 2011, Rayon 07, University of Lampung. Bandar Lampung

Mulyana (2017). Competency of Elementary School Physical
Education Teachers. Journal Parameter Volume 29 No. 1 Year 2017. P $39-45$

Pujianto and Insanistyo (2014) Mapping the Profile and Competence of Physical Education and Health Teachers at Elementary School Level in Bengkulu City. Indonesian Journal of Physical Education Volume 10, Number 1, April 2014

Princess andPriambodo (2015). The Effect of Self-Efficacy, Goal Setting and Job Satisfaction on Competency Development of Physical Education, Sports and Health Teachers (Study on Physical Education, Sports and Health Teachers in Public Senior High Schools in Surabaya City). Journal of Sports and Health Education Volume 03 Number 01 of 2015, $220-226$

Rahmawantiet al. (2014). The Effect of Work Environment on Employee Performance(Study on employees of the North Malang Pratama Tax Service Office). Journal of Business Administration (JAB) Volume 8 Number 2 March 2014. 